\title{
JOURNAL OF AGRICULTURE AND APPLIED BIOLOGY
}

2021, Vol. 2, No. 1, 1 - 10

http://dx.doi.org/10.11594/jaab.02.01.01

\section{Research Article}

\section{Morpho-physiological responses in wheat (Triticum aestivum $L$ ) influenced by normal and water stress conditions}

\author{
Piar Ali Shar ${ }^{*}$ (D) Akhtar Hussain Shar2, Shabana Memon ${ }^{1}$, Ayaz Ali Soomro ${ }^{3}$, Saleem \\ Ahmed Naich ${ }^{4}$, Nadir Ali Rind ${ }^{2}$, Asadullah Laghari ${ }^{1}$, Khalid Hussain Rind ${ }^{2}$, Parkash \\ Meghwar $^{5}$ (D), Sohail Ahmed Otho 6
}
1Department of Plant Breeding and Genetics, Faculty of Crop Production, Sindh Agriculture University Tandojam, 70060, Sindh, Pakistan
${ }^{2}$ School of Molecular Biology and Genetics, Shaheed Benazir Bhutto University, Banazirabad, Sindh, Pakistan
${ }^{3}$ Department of Plant Breeding and Genetics, Subcampus Umerkot, Sindh Agriculture University, Tandojam, Sindh, Pakistan
${ }^{4}$ Faculty of Agricultural Engineering, Sindh Agriculture University Tandojam, 70060, Sindh, Pakistan.
5Institute of Food Sciences and Technology, Sindh Agriculture University, Tandojam, 70060, Sindh, Pakistan.
${ }^{6}$ Department of Entomology, Sindh Agriculture University, Tandojam, 70060, Sindh, Pakistan.

Article history:

Submitted 19 October 2020

Accepted 11 March 2021

Published 14 April 2021

Keywords:

Heritability

Leaf area

Osmotic potential

Phonological traits

Relative water content

*Corresponding author:

E-mail:

drpiaralishar@gmail.com

\begin{abstract}
Drought is a disaster around the world accumulating salt and erosion in lands. Presently, a research was conducted to determine the morpho-physiological response in bread wheat under normal and stress irrigations. This experiment was conducted at the experimental field of Sindh Agriculture University, Tandojam, Hyderabad, Pakistan, for two consecutive years during the Rabi season of the year 2011-12 and 2012-13. Stress was imposed by withholding irrigations at three different growth stages of the plant, i.e. $\mathrm{T}_{1}$ : normal irrigations applied, $\mathrm{T}_{2}$ : stress at tillering stage, and $\mathrm{T}_{3}$ : stress at the booting stage. The progenies Sarsabz x Khirman and Sarsabz x TD-1 contributed the highest heritability\% (81.0\% and $85.5 \%)$ for osmotic potential ($\mathrm{MPa}$ ) at stress at booting stage. For grain yield spike-1 $(\mathrm{g})$, the progeny Kiran-95 x Khirman showed maximum heritability as 84.37 in $\mathrm{T}_{3}$. However, the progeny TD-1 x Imdad proved to be the best combiner progeny indicating highest heritability percentage (91.0\%) among the progenies for grain yield at booting stress.
\end{abstract}

\section{Introduction}

Bread wheat is the primary source of human food containing high protein content than other major cereal crops (Chen et al., 2012). Wheat is considered not only the major cereal crop of the world, but it is also the critical staple

\section{How to cite:}

Shar, P. A., Shar, A. H., Memon, S., Soomro, A. A., Naich, S. A., Rind, N. A., Asadullah Laghari, A. \& Rind, K. H., Meghwar, P., \& Otho, S. A. (2021). Morpho-physiological responses in wheat (Triticum aestivum $L$ ) influenced by normal and water stress conditions. Journal of Agriculture and Applied Biology, 2(1): 1 - 10. doi: 10.11594/jaab.02.01.01 
food of inhabitants of Pakistan (Mirbahar et al., 2009). Pakistan experiences a variety of climate, and one-third of the total acreage is rainfed areas (Mirbahar et al., 2009). Due to climatic change and increase in temperature the wheat crop is being affected and addressed at the global level (Sial et al., 2012). Drought threat may emerge to low productivity and limit the plant growth (Simova-Stoilova et al., 2006; Khan and Naqvi, 2011; Xu et al., 2018).

Drought tolerance cannot be considered as a simple response to the plant, but some components interact with each other and may vary at different crops, also my response to different types, intensity, and duration of water deficit (Gajewska et al., 2018). Many investigators have suggested that drought stress tolerance can be studied through genetic improvement of physiological traits, also including essential traits such as harvest index and biological yield (Mohammadi et al., 2006). Drought stress directly affects biochemical, and physiology of the plant and the changes is observed by the variable decline of the leaf relative water content (RWC) which is a better indicator of plant water status (Siddique et al., 2000; Vicente et al., 2018). Previous studies have reported that any alteration in the environmental parameters will change the genetic architecture of the traits (Zhang et al., 2018; Li et al., 2018).

Breeding and selection of high heritable traits that provide tolerance to drought will provide valuable information to the breeders to predict the interaction of genes in segregating populations under stress environments (Jatoi et al., 2011; Khan and Naqavi, 2011; Sial et al., 2013). Statistical parameters such as variance, heritability, and genetic advance are a useful measure to evaluate genetic stability and performance of any genotype of a particular trait in that genotype (Firouzian, 2003). The suitable criteria of the crop for selecting high yield performance are low yield, mean productivity and relative yield performance in drought and more favorable environments (Ahmad et al., 2003). Hence, heritability, therefore, increases when it is used to calculate genetic advance, which indicates the degree of gain in character obtained under particular selection pressure (Shukla et al., 2004). Keeping given the above findings, some physiological and phonological parameters were studied to observe the response of the genotypes/hybrids under water stress and non-stress environments.

\section{Materials and methods}

\section{Plant materials}

Six different bread wheat local cultivars were used for this experiment having high yield and good quality traits. Furthermore, in the second year, six valuable cross combinations viz. TD-1 $\times$ Imdad, Sarsabz $\times$ TD-1, TJ-83 $\times$ Khirman, Kiran-95 $\times$ Khirman, Sarsabz $\times$ TJ-83 and Sarsabz $\times$ Khirman were study.

\section{Experiment design and planting method}

The experiment was conducted at Latif farm, the experimental field of Sindh Agriculture University, Tandojam, Hyderabad, Pakistan, for two years during the Rabi season of the year 2011-12 and 2012-13. The innovative design was split plot design along with three replications. In the first-year irrigation was escaped at different stages of growth cycle. In the $2^{\text {nd }}$ generation the crosses developed were grow into assess under different irrigation stages of wheat, evaluating under water stress and non-stress conditions. All agronomical practices such as weeding, rouging was performed as usual for parental lines and offsprings and all were equally treated.

\section{Data analysis and observations to be recorded}

Genotypic variance, environmental variance, heritability percentage in broad sense, heritability coefficient was calculated as suggested by (Falconer, 1984).

The genotypes were exposed to three different water treatments as below:

$\mathrm{T}_{1} \quad$ : normal irrigations all normal or wellirrigated; 5 irrigations

$\mathrm{T}_{2} \quad$ : Stress induced at tillering stage

$\mathrm{T}_{3}$ : Stress induced at booting stage

The physiological and phonological traits including leaf area $\left(\mathrm{cm}^{2}\right)$, relative water content (\%), osmotic potential (-MPa), biological yield (Kg ha-1), harvest index (\%) and grain yield/spike (g) were recorded and studied. 


\section{Statistical analysis}

The entire data was statistically analyzed using Analysis of variance (ANOVA) according to (Gomez \& Gomez, 1984). All the data was statistically analyzed, standard error for difference between means (SED) and Least Significant Difference (LSD) were calculated using the following formula: $\mathrm{SED}=(2 \mathrm{EMS} / \mathrm{N})^{1 / 2} \mathrm{LSD}=$ SED $\times \mathrm{t}(0.05) \mathrm{df}$

Where, EMS = error mean square; $\mathrm{n}=$ number of replications.

$\mathrm{t}(0.05) \mathrm{df}=$ value from the $\mathrm{t}$ distribution table at 5\% probability level and error degree of freedom. Significance levels are shown in the tables at $0.05 \%$, and $0.01 \%$ probability levels, respectively. The non-significant differences are mentioned as N.S.

\section{Results and discussion}

In the present study, the results of mean performance for the trait biological yield (Kg ha $^{-1}$ ) have indicated that $F_{2}$ progenies were significantly decreased $(2737$ biological yield $\mathrm{kg}$ ha $^{-1}$ ) in $\mathrm{T}_{3}$ with $107.0 \%$ reduction as compare to $\mathrm{T}_{1}$, i.e., normal irrigations (Figure 1, 3822 biological yield $\mathrm{kg} \mathrm{ha}^{-1}$ ). Harvest index $\%$ reduced with $13.8 \%$ in $\mathrm{T}_{2}$ and $37.4 \%$ in $\mathrm{T}_{3}$ as compared to $\mathrm{T}_{1}$ (Figure 2). From previous studies it has been observed that the harvest index (\%) and biological yield (Kg ha ${ }^{1}$ ) decreased under drought stress conditions (Sial et al., 2010). Moreover, drought stress reduces crop yield regardless of the growth stage at which it occurs in wheat (Ma et al., 2012; Li et al., 2018). The results regarding grain yield (g) depicted the significant decrease in $F_{2}$ generation in $T_{3}$ $(1.0 \mathrm{~g})$ which showed reduction $(70 \%)$ followed by $\mathrm{T}_{2}$ (Figure 3 ). Consequently, the physiological traits were also observed to be affected in the $\mathrm{F}_{2}$ progenies. Relative water content $\%$ significantly reduced with $28.9 \%$ and $8.0 \%$ in $\mathrm{T}_{3}$ and $\mathrm{T}_{2}$ respectively, as compared to normal irrigation $\mathrm{T}_{1}$ (Figure 4). Whereas leaf area $\left(\mathrm{cm}^{2}\right)$ and Osmotic potential (-MPa) showed reduction of $34.2 \%$ and $25.6 \%$ in $\mathrm{T}_{3}$ as compared to $\mathrm{T}_{1}$ (Figure 4 \& Figure 5). Different studies on water relations under drought effects have declared that water stress at vegetative and anthesis stages both directly leads to decrease in leaf water potential and relative water content (Siddique et al., 2000).

Accordingly, the genetic parameters studied under drought and non-stress conditions revealed a variable response to the physiological and phonological traits. The physiological trait leaf area $\left(\mathrm{cm}^{2}\right)$ profound to have high heritability (b.s) in the progenies TD-1x Imdad, TJ83 x Khirman and Sarsabz x TJ-83 (85.0, 83.3, $80.0 \%$ ) coupled with more genetic advance in $\mathrm{T}_{1}$. In $\mathrm{T}_{2}$, moderate to low heritability was presented reflecting drought stress effect during this stage. Sarsabz x TD-1 (54.9\%), Sarsabz x Khirman (54.2) and Sarsabz x TJ- 83 (54.0) progenies considered to have moderate heritability $\%$ in $\mathrm{T}_{2}$. In $\mathrm{T}_{3}$ also TD-1 x Imdad and Sarsabz x Khirman $(58.3,58.0)$ revealed moderate heritability\% with genetic advance (Table 1). For the trait relative water content \%, maximum heritability\% was seen in the progeny Sarsabz x TD-1 coupled with more genetic advance $\left(\mathrm{h}^{20} \%=78.0, \mathrm{GA}=6.9\right)$ in $\mathrm{T}_{1}$. Plants coping with higher RWC under drought stress conditions are mentioned to have high and medium yields, whereas decrease in RWC depends on the plant vigor reduction (Arjenaki et al., 2012). With the trait osmotic potential (-MPa), highest heritability \% was revealed in $\mathrm{T}_{1}$ by two progenies, Sarsabz x TD-1 (85.5\%) and Sarsabz $x$ Khirman (81.0\%). In $\mathrm{T}_{2}$ almost all the progenies revealed high heritability \% coupled with genetic advance except Kiran-95 x Khirman (15.0), emphasizing low osmotic potential ($\mathrm{MPa}$ ). However, in $\mathrm{T}_{3}$ Sarsabz $\mathrm{x}$ Khirman and Sarsabz x TD-1 $(87.0,83.0)$ contributed maximum heritability percentage, while others revealed moderate to low heritability with genetic advance in $\mathrm{T}_{3}$ for osmotic potential (MPa) (Table 3).

In $\mathrm{T}_{1}$, heritability $\%$ for biological yield $(\mathrm{Kg}$ ha $^{-1}$ ) in $\mathrm{F}_{2}$ segregating progenies range from $43.7 \%$ in Kiran-95 x Khirman to $89.3 \%$ in TJ-83 $\mathrm{x}$ Khirman (Table 4). In this trait the progenies Sarsabz x TD-1, Sarsabz x TJ-83, TD-1x Imdad, and TJ-83 $x$ Khirman showed the highest heritability (b.s) coupled with more genetic advance. Whereas in $\mathrm{T}_{2}$ the heritability percentage $\left(\mathrm{h}^{2}\right)$ ranged from $44.44 \%$ to $80.5 \%$ in Sarsabz x TD-1 and TD-1 x Imdad, respectively. 
Three progenies TD-1 x Imdad, TJ-83 x Khirman and Sarsabz $x$ Khirman attributed maximum heritability (b.s) i.e., 80.5, 70.66 and $75.0 \%$ with genetic advance (G.A 46.3, 7.27, and $8.88 \%$ ) in $\mathrm{T}_{2}$, respectively. At stress during booting stage $\left(\mathrm{T}_{3}\right)$ Sarsabz $\mathrm{x}$ Khirman and Kiran-95 x Khirman provided maximum heritability (b.s \%) with genetic advance $(80 \%)$ revealing that these progenies tolerated with high inheritance for biological yield trait (Table 4). Subsequently, for harvest index $\%$ the heritability found to be more in three progenies viz TJ-83 x Khirman (84.2\%), Sarsabz x TJ-83, (63.8\%) and Sarsabz x Khirman (93.7\%) in $\mathrm{T}_{1}$. In $\mathrm{T}_{2}$ and $\mathrm{T}_{3}$ Kiran-95 x Khirman displayed maximum heritability indicating that the genetic variability has been successfully produced for this particular trait in $\mathrm{F}_{2}$ progeny (Table 5).

Grain yield, a complex quantitative trait (Moghadam et al., 2014) showed high heritability in the progeny TJ-83 x Khirman (86.8\%) in
$\mathrm{T}_{1}$. Regarding $\mathrm{T}_{2}$ and $\mathrm{T}_{3}$ Kiran-95 $\mathrm{x}$ Khirman (69.47\%) and TD-1 x Imdad (91.0\%) exhibited maximum heritability, in stress conditions. Similarly, other progenies influenced moderate to low heritability with genetic advance under stressed environments, which seems that they were affected by one escape of irrigation at either tillering or booting stages (Table 6). Hence, it can be suggested that those genotypes/hybrids integrating high heritability with genetic advance under stress environments may control tolerant genes and could be implied for further breeding programs. The physiological and morphological traits have a great interaction between them concerned with yield production as previous investigations declare that high osmotic potential and other physiological traits is concerned directly with high yield (Sial et al., 2010).

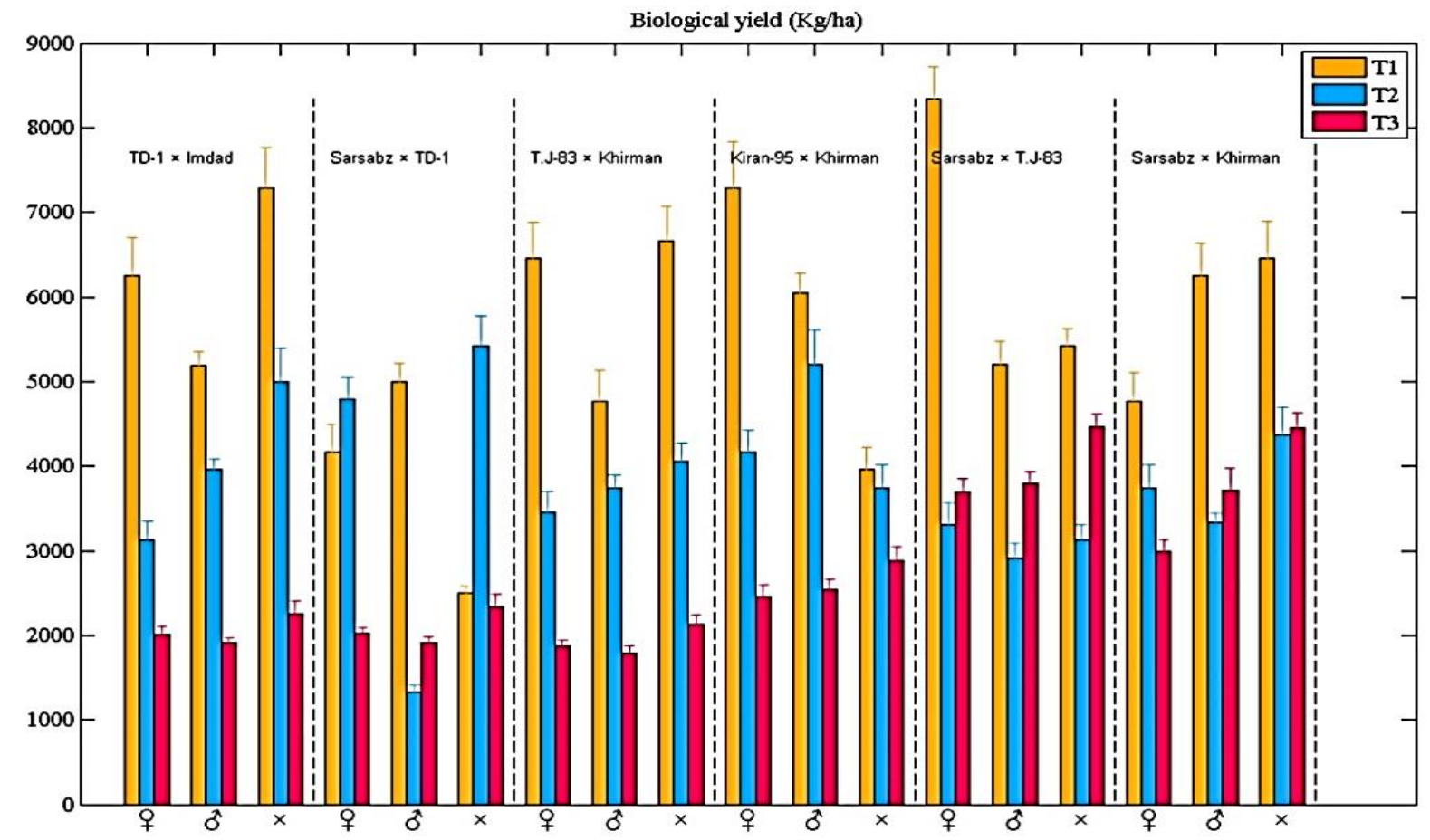

Figure 1. Reduction (\%) values of six $F_{2}$ progenies and their respective parental lines of wheat for biological yield $\left(\mathrm{Kg} \mathrm{ha}^{-1}\right)$ at different irrigations 


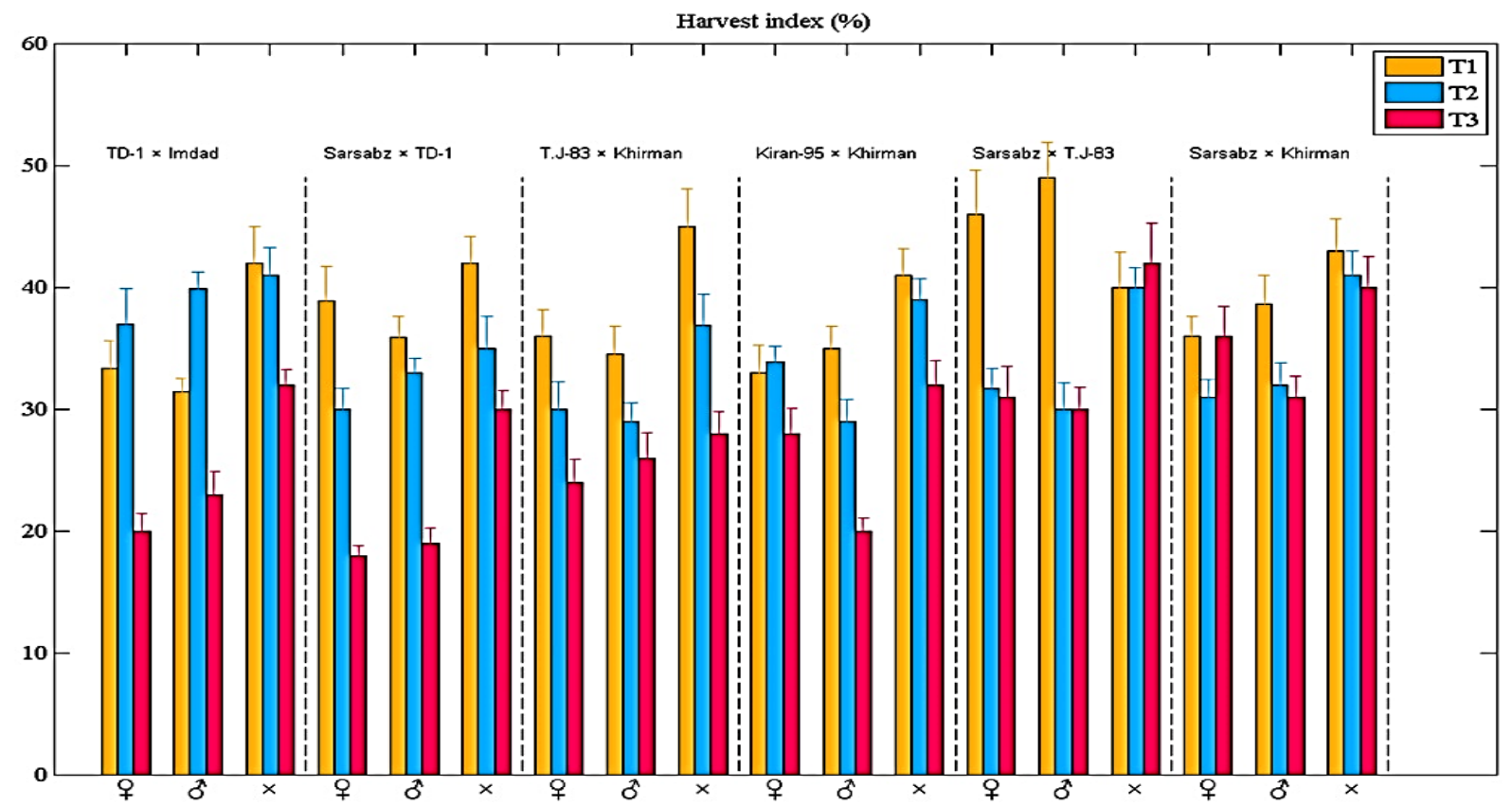

Figure 2. Reduction (\%) values of six $F_{2}$ progenies and their respective parental lines of wheat for harvest index (\%) at different irrigations

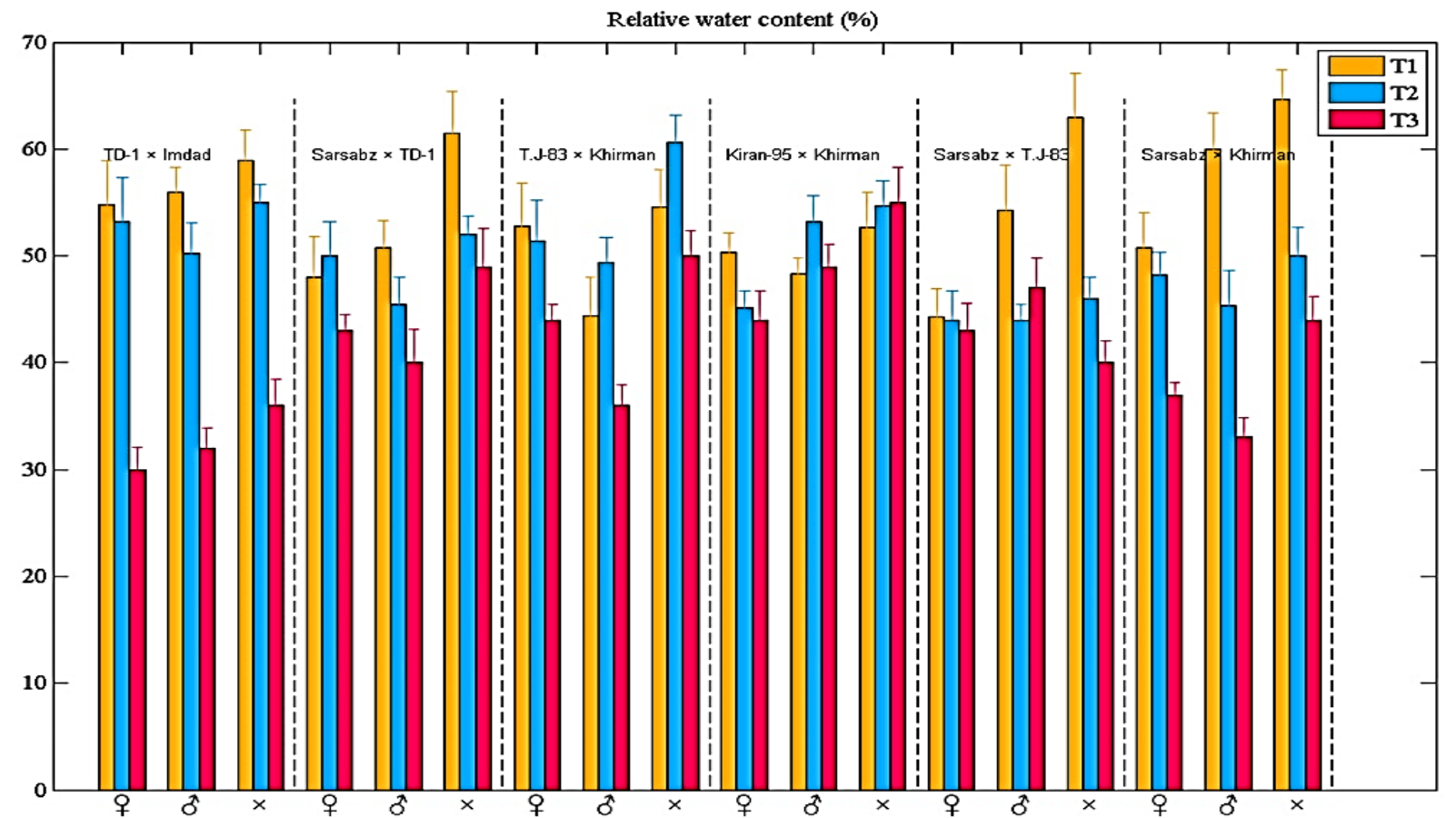

Figure 3. Reduction (\%) values of six $F_{2}$ progenies and their respective parental lines of wheat for relative water content (\%) at different irrigations 


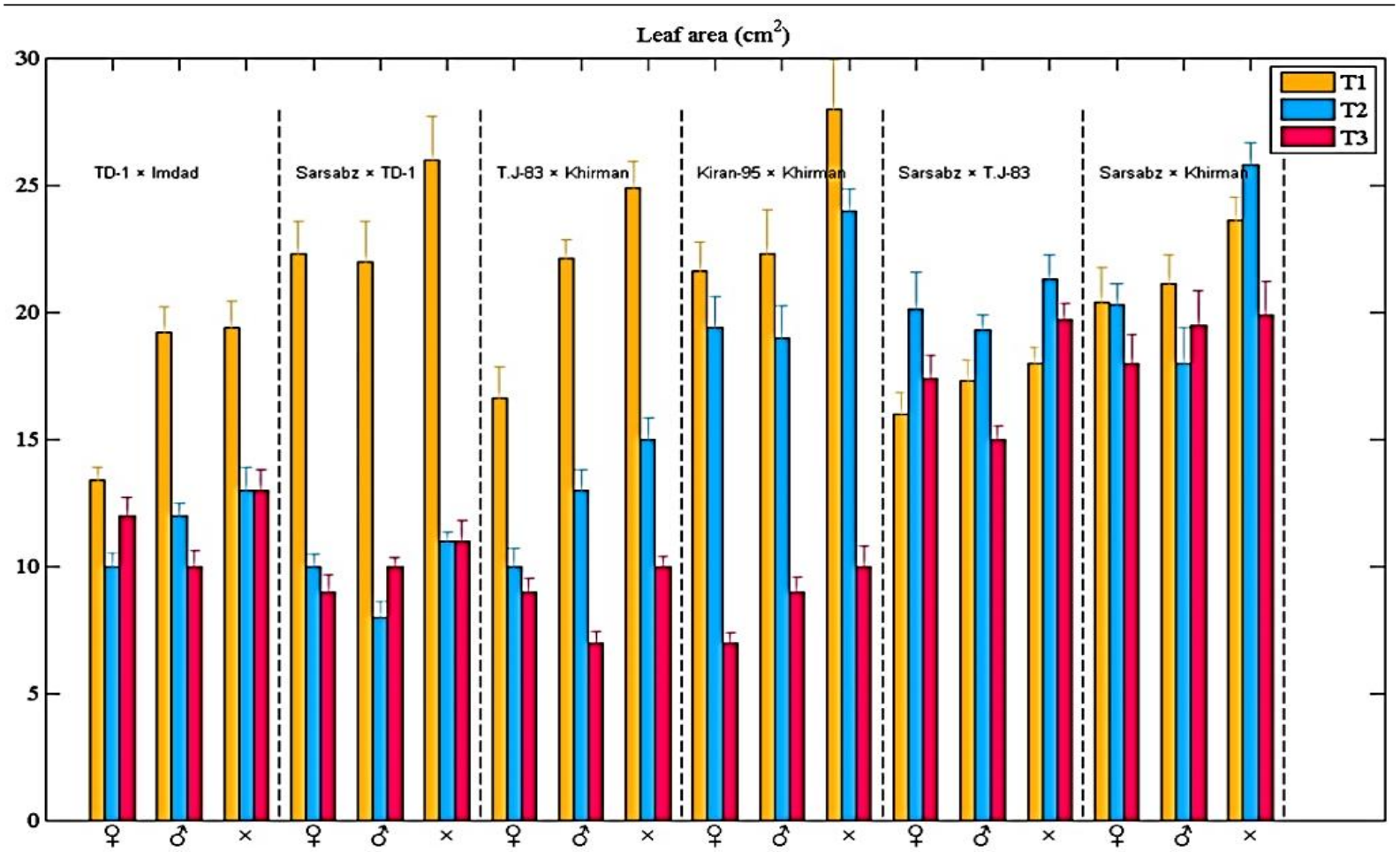

Figure 4. Reduction (\%) values of six $F_{2}$ progenies and their respective parental lines of wheat

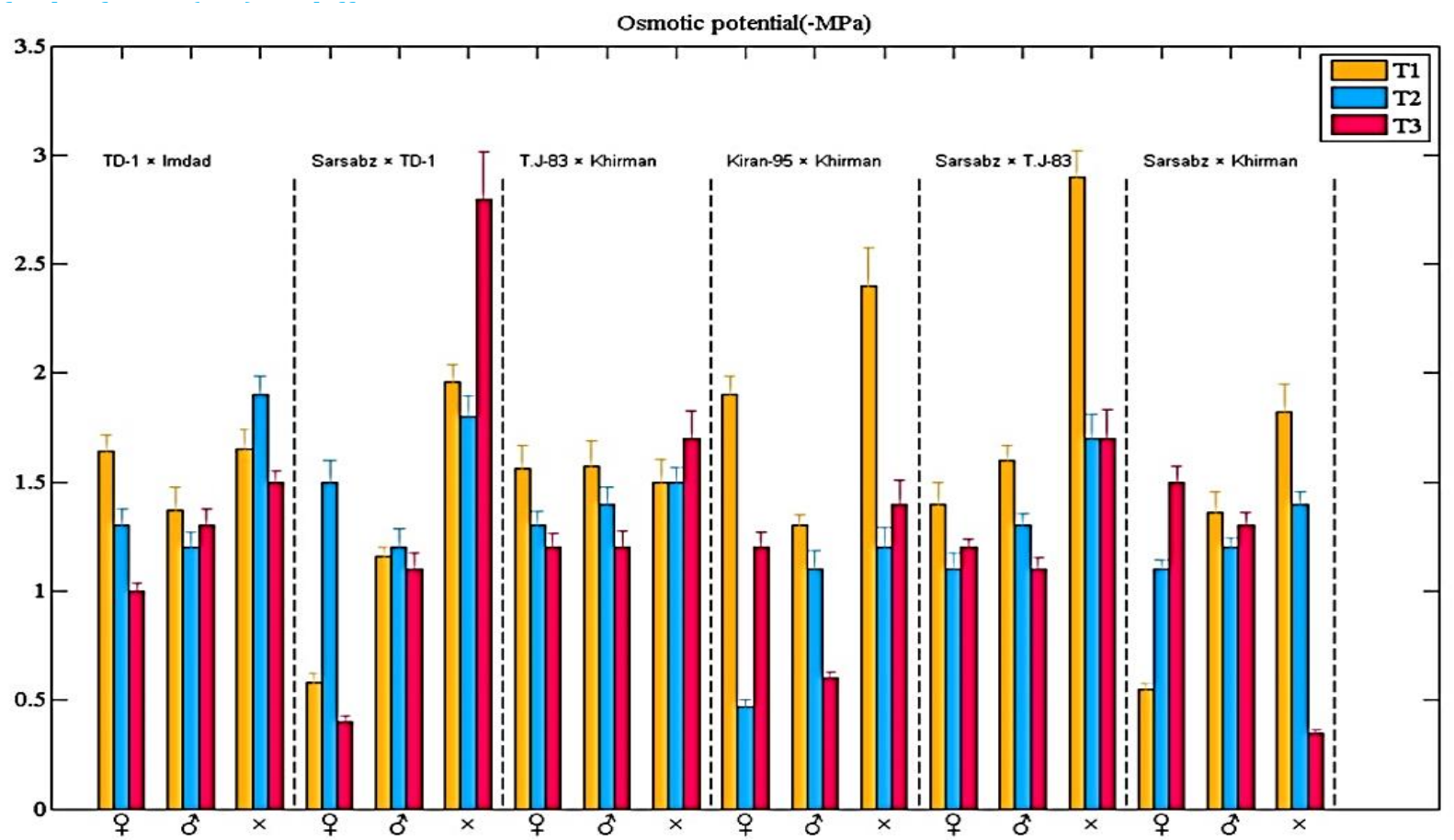

Figure 5. Reduction (\%) values of six $F_{2}$ progenies and their respective parental lines of wheat for osmotic potential (-MPa) at different irrigations 
Table 1. Heritability percentage ( $h^{2} \%$ broad. sense) and genetic advance (GA) of six $F_{2}$ progenies in wheat for leaf area $\left(\mathrm{cm}^{2}\right)$

\begin{tabular}{lllllll}
\hline \multirow{2}{*}{$\mathrm{F}_{2}$ progenies } & \multicolumn{7}{c}{ Leaf area $\left(\mathrm{cm}^{2}\right)$} \\
\cline { 2 - 7 } & \multicolumn{2}{c}{$\mathrm{T}_{1}$} & \multicolumn{2}{c}{$\mathrm{T}_{2}$} & \multicolumn{3}{c}{$\mathrm{T}_{3}$} \\
\cline { 2 - 7 } & $\mathrm{h}^{2} \%$ & $\mathrm{GA}$ & $\mathrm{h}^{2} \%$ & $\mathrm{GA}$ & $\mathrm{h}^{2} \%$ & $\mathrm{GA}$ \\
\hline TD-1 x Imdad & 85.00 & 7.5 & 16.60 & 0.5 & 58.30 & 2.1 \\
\hline Sarsabz x TD-1 & 72.00 & 5.1 & 54.90 & 2.6 & 45.80 & 2.2 \\
\hline TJ-83 x Khirman & 83.30 & 2.9 & 33.30 & 1.4 & 41.50 & 2.0 \\
\hline Kiran-95 x Khirman & 70.80 & 3.5 & 12.50 & 0.3 & 25.00 & 0.7 \\
\hline Sarsabz x TJ- 83 & 80.00 & 5.7 & 54.00 & 2.6 & 16.60 & 0.8 \\
\hline Sarsabz x Khirman & 78.00 & 5.6 & 54.20 & 2.6 & 58.00 & 2.8 \\
\hline
\end{tabular}

Table 2. Heritability percentage ( $h^{2} \%$ broad. sense) and genetic advance (GA) of six $F_{2}$ progenies in wheat for Relative water content (\%)

\begin{tabular}{lllllll}
\hline \multirow{2}{*}{ F2 progenies } & \multicolumn{7}{c}{ Relative water content (\%) } \\
\cline { 2 - 7 } & \multicolumn{2}{c}{$\mathrm{T}_{1}$} & \multicolumn{3}{c}{$\mathrm{T}_{2}$} & \multicolumn{3}{c}{$\mathrm{T}_{3}$} \\
\cline { 2 - 7 } & $\mathrm{h}^{2} \%$ & $\mathrm{GA}$ & $\mathrm{h}^{2} \%$ & $\mathrm{GA}$ & $\mathrm{h}^{2} \%$ & $\mathrm{GA}$ \\
\hline TD-1 x Imdad & 38.40 & 1.9 & 76.60 & 4.2 & 76.00 & 7.0 \\
\hline Sarsabz x TD-1 & 78.00 & 6.9 & 58.30 & 2.8 & 62.50 & 6.1 \\
\hline TJ-83 x Khirman & 18.20 & 0.8 & 60.00 & 1.8 & 44.40 & 1.9 \\
\hline Kiran-95 x Khirman & 88.00 & 8.4 & 70.00 & 2.9 & 77.20 & 9.0 \\
\hline Sarsabz x TJ- 83 & 86.50 & 7.6 & 58.30 & 2.8 & 47.30 & 2.9 \\
\hline Sarsabz x Khirman & 68.40 & 6.0 & 62.00 & 3.0 & 44.70 & 2.7 \\
\hline
\end{tabular}

Table 3. Heritability percentage ( $h^{2} \%$ broad. sense) and genetic advance (GA) of six $F_{2}$ progenies in wheat for Osmotic potential (-MPa)

\begin{tabular}{lllllll}
\hline \multirow{2}{*}{ F $_{2}$ progenies } & \multicolumn{7}{c}{ Osmotic potential (-MPa) } \\
\cline { 2 - 7 } & \multicolumn{2}{c}{$\mathrm{T}_{1}$} & \multicolumn{2}{c}{$\mathrm{T}_{2}$} & \multicolumn{3}{c}{$\mathrm{T}_{3}$} \\
\cline { 2 - 7 } & $\mathrm{h}^{2} \%$ & $\mathrm{GA}$ & $\mathrm{h}^{2} \%$ & $\mathrm{GA}$ & $\mathrm{h}^{2} \%$ & $\mathrm{GA}$ \\
\hline TD-1 x Imdad & 50.00 & 0.2 & 97.00 & 0.4 & 42.00 & 0.2 \\
\hline Sarsabz x TD-1 & 85.50 & 0.5 & 96.00 & 1.0 & 83.00 & 0.8 \\
\hline TJ-83 x Khirman & 35.00 & 0.1 & 80.60 & 0.5 & 44.40 & 0.5 \\
\hline Kiran-95 x Khirman & 35.00 & 0.4 & 15.00 & 0.0 & 73.00 & 0.6 \\
\hline Sarsabz x TJ- 83 & 36.10 & 0.3 & 96.20 & 0.9 & 66.00 & 0.7 \\
\hline Sarsabz x Khirman & 81.00 & 0.5 & 80.90 & 0.8 & 87.00 & 1.0 \\
\hline
\end{tabular}

Note: low heritability: less than 0.20 ; moderate heritability: scores of $0.21 ; 0.40$;

High heritability: scores above 0.40 
Table 4. Heritability percentage ( $h^{2} \%$ broad. sense) and genetic advance (GA) of six $F_{2}$ progenies in wheat for Biological yield ( $\left.\mathrm{Kg} \mathrm{ha}^{-1}\right)$

\begin{tabular}{lrrrrrrr}
\hline & \multicolumn{7}{c}{ Biological yield (Kg ha-1) } \\
\cline { 2 - 8 } F $_{2}$ progenies & \multicolumn{3}{c}{$\mathrm{T}_{1}$} & \multicolumn{3}{c}{$\mathrm{T}_{2}$} & \multicolumn{3}{c}{$\mathrm{T}_{3}$} \\
\cline { 2 - 8 } & $\mathrm{h}^{2} \%$ & $\mathrm{GA}$ & $\mathrm{h}^{2} \%$ & $\mathrm{GA}$ & $\mathrm{h}^{2} \%$ & $\mathrm{GA}$ \\
\hline TD-1 x Imdad & 74.00 & 26.1 & 80.50 & 46.3 & 68.00 & 8.9 \\
\hline Sarsabz x TD-1 & 80.00 & 23.4 & 44.44 & 7.4 & 23.80 & 1.9 \\
\hline TJ-83 x Khirman & 89.30 & 49.0 & 70.66 & 7.2 & 66.00 & 15.0 \\
\hline Kiran-95 x Khirman & 43.70 & 10.3 & 67.80 & 4.7 & 99.00 & 29.0 \\
\hline Sarsabz x TJ- 83 & 76.00 & 8.8 & 50.44 & 2.8 & 80.00 & 21.0 \\
\hline Sarsabz x Khirman & 60.00 & 7.3 & 75.00 & 8.8 & 98.00 & 22.0 \\
\hline
\end{tabular}

Table 5. Heritability percentage ( $h^{2} \%$ broad. sense) and genetic advance (GA) of six $F_{2}$ progenies in wheat for Harvest index (\%)

\begin{tabular}{|c|c|c|c|c|c|c|}
\hline \multirow{3}{*}{$\mathrm{F}_{2}$ progenies } & \multicolumn{6}{|c|}{ Harvest index (\%) } \\
\hline & \multicolumn{2}{|c|}{$\mathrm{T}_{1}$} & \multicolumn{2}{|c|}{$\mathrm{T}_{2}$} & \multicolumn{2}{|c|}{$\mathrm{T}_{3}$} \\
\hline & $\mathrm{h}^{2} \%$ & GA & $\mathrm{h}^{2} \%$ & GA & $\mathrm{h}^{2} \%$ & GA \\
\hline TD-1 x Imdad & 25.00 & 1.2 & 86.00 & 7.8 & 55.60 & 7.4 \\
\hline Sarsabz x TD-1 & 59.90 & 13.9 & 73.00 & 8.2 & 57.70 & 8.8 \\
\hline TJ-83 x Khirman & 84.20 & 15.6 & 26.20 & 3.4 & 21.00 & 1.9 \\
\hline Kiran-95 x Khirman & 49.80 & 7.0 & 89.00 & 9.8 & 78.00 & 9.4 \\
\hline Sarsabz x TJ- 83 & 63.80 & 14.8 & 26.20 & 3.4 & 41.30 & 9.1 \\
\hline Sarsabz x Khirman & 93.70 & 9.0 & 38.30 & 4.3 & 58.00 & 8.9 \\
\hline
\end{tabular}

Table 6. Heritability percentage ( $h^{2} \%$ broad. sense) and genetic advance (GA) of six $F_{2}$ progenies in wheat for Grain yield spike ${ }^{1}(\mathrm{~g})$

\begin{tabular}{lcccccc}
\hline & \multicolumn{7}{c}{ Grain yield spike ${ }^{1}(\mathrm{~g})$} \\
\cline { 2 - 7 } F $_{2}$ progenies & \multicolumn{2}{c}{$\mathrm{T}_{1}$} & \multicolumn{3}{c}{$\mathrm{T}_{2}$} & $\mathrm{~T}_{3}$ \\
\cline { 2 - 7 } & $\mathrm{h}^{2} \%$ & $\mathrm{GA}$ & $\mathrm{h}^{2} \%$ & $\mathrm{GA}$ & $\mathrm{h}^{2} \%$ & $\mathrm{GA}$ \\
\hline TD-1 x Imdad & 75.80 & 0.3 & 48.57 & 0.5 & 91.00 & 1.2 \\
\hline Sarsabz x TD-1 & 82.06 & 0.7 & 46.00 & 0.3 & 35.00 & 0.2 \\
\hline TJ-83 x Khirman & 86.80 & 0.5 & 18.22 & 0.5 & 84.61 & 2.9 \\
\hline Kiran-95 x Khirman & 61.11 & 0.2 & 69.47 & 1.4 & 84.37 & 1.0 \\
\hline Sarsabz x TJ- 83 & 82.37 & 1.5 & 48.66 & 0.3 & 60.00 & 0.3 \\
\hline Sarsabz x Khirman & 82.06 & 1.3 & 28.66 & 0.2 & 65.00 & 0.4 \\
\hline
\end{tabular}

\section{Conclusion}

Water stresses consequently reduce the overall yield of crops. To overcome these facts, current study was conducted to identify the potentiality for tolerance as well as for yield performance in selected bread wheat lines. In 
current study, a detailed examination on the morpho-physiological responses to water stress in six different bread wheat crossed cultivars including Imdad $\times$ TD- $1 \times$ Kiran $-95 \times$ Khirman $\times$ Sarsabz $\times$ TJ -83 was conducted. Results suggested genetic improvement as well as tolerance ability in several traits. For instance, a comparative analysis suggested the potential of heritability \% for osmotic potential (-MPa) in progenies Sarsabz $\times$ Khirman and Sarsabz $\times$ TD-1. Similarly, progeny Kiran-95 $\times$ Khirman also performed well with maximum heritability with genetic advance for harvest index $\%$ and grain yield. Despite these results, our examination found that the progeny TD- $1 \times$ Imdad was worth cross with a significantly higher heritability $\%$ of $90 \%$ for grain yield as well as for trait comparative water content $\%$ among all other crosses. These results opened the way for further advance research and provided a potential reference for genetic improvement of suggested cultivars for better yield, as well as for tolerance in water stress conditions.

\section{Author declaration}

Authors declare that there is no conflict of interest. Conceived and designed the experiments: PAS. Performed the experiments: PAS, AHS. Analyzed the data: SM \& SAN. Contributed materials/analysis/tools: AL, AAS, NAR, SAO, \& KHR. Wrote the paper: PAS. PM advised about format and proofreading before submission. All authors read and approved the final version of the manuscript.

\section{References}

Ahmad, R. S., Qadir, N., Ahmad, \& Shah, K. H. (2003). Yield potential and stability of nine wheat varieties under water stress conditions. International Journal of Agriculture \& Biology, 5, 7-9. CrossRef

Arjenaki, F. G., Jabbari, R., \& Morshedi, A. (2012).

Evaluation of drought stress on relative water content, chlorophyll content and mineral elements of wheat (Triticum aestivum L.) varieties. International Journal of Agriculture and Crop Science, 4, 726-729. Corpus ID: 13112769

Chen, X., Min, D. T. A., Yasir, \& Hu, Y.G. (2012). Evaluation of 14 morphological, yield-related and physiological traits as indicators of drought tolerance in Chinese winter bread wheat revealed by analysis of the membership function value of drought tolerance (MFVD). Field Crops Research, 137, 195-201. CrossRef

Falconer, D. S., (1984). Einfuehrung in die quantitative genetik. UTB fuer Wissenschaft: Uni-Taschenbuecher (Germany). 1334; CrossRef

Firouzian, A., 2003 Heritability and genetic advance of grain yield and its related traits in wheat. Pakistan Journal of Biological Sciences, 4, 2020-2023. CrossRef

Gajewska, E., Głowacki, R., Mazur, J., \& Sklodowska, M. (2013). Differential response of wheat roots to cu, ni and cd treatment: oxidative stress and defense reactions. Plant Growth Regulation 71(1), 13-20. CrossRef

Gomez, K. A., \& Gomez, A. A. (1984). Statistical procedures for agricultural research. John Wiley \& Sons. CrossRef

Jatoi, W., Baloch, M., Kumbhar, M., Khan, N., \& Kerio, M. (2011). Effect of water stress on physiological and yield parameters at anthesis stage in elite spring wheat cultivars. Sarhad Journal of Agriculture, 27, 59-65. CrossRef

Khan, N., \& Naqvi, F. (2011). Effect of water stress in bread wheat hexaploids. Current Research Journal of Biological Science, 3, 487-498.

Hu, L., Xie, Y., Fan, S., Wang, Z., Wang, F., Zhang, B., \& Kong, L. (2018). Comparative analysis of root transcriptome profiles between drought-tolerant and susceptible wheat genotypes in response to water stress. Plant Science, 272, 276-293. CrossRef

Li, G., Peng, X., Xuan, H., Wei, L., Yang. Y., Guo, T., \& Kang, G. (2013). Proteomic analysis of leaves and roots of common wheat (Triticum aestivum L.) under copper-stress conditions. Journal of Proteome Research, 12 (11), 4846. CrossRef

Mirbahar, A. A., Markhand, G., Mahar, A., Abro, S. A., \& Kanhar, N. A. (2009). Effect of water stress on yield and yield components of wheat (Triticum aestivum L.) varieties. Pakistan Journal of Botany, 41, 13031310. CrossRef

Moghadam, P. A., Alaei, Y. E., \& Khabiri, Y. (2014). Evaluation of yield and some morphological traits of wheat varieties under drought stress. International Journal of Plant, Animal and Environmental Science 4(2), 121-125.

Mohammadi, M., Ceccarelli, S., \& Naghavi, M. (2006). Variability and genetic parameters for related traits to drought tolerance in doubled haploid population 
of barley (Hordeum vulgare). International Journal of Agriculture and Biology 8(5), 694-697. CrossRef Raza, S., Saleem, M. F., Khan, I. H., Jamil, M., Ijaz, M., \& Khan, M. A. (2012). Evaluating the drought stress tolerance efficiency of wheat (Triticum aestivum L.) cultivars. Russian Journal of Agricultural and SocioEconomic Sciences, 12(12), 41-46 CrossRef

Shukla, S., Bhargava, A. A., Chatterjee, \& Singh, S. (2004). Estimates of genetic parameters to determine variability for foliage yield and its different quantitative and qualitative traits in vegetable amaranth (A. tricolor)[India]. Journal of Genetics and Breeding, 58(2), 169-176.

Sial, M. A., Dahot, M. U., Mangrio, S. Arain, M. K., \& Laghari, A. (2010). Screening of wheat genotypes for water stress tolerance. Pakistan Journal of Biotechnology, 7 (1-2), 137-143.

Sial, M., Laghari, K. A., Panhwar, N. A., Arain, M. A., \& Baloch, G. M. (2012). Genetic improvement of drought tolerance in semi-dwarf wheat. Journal of Technology and Development 31(4), 335-340. CrossRef

Sial, M. A., Akhter, J., Mirbahar, A. A., Jamali, K. D., \& Ahmed, N. (2013). Genetic studies of some yield contributing traits of $\mathrm{f}-2$ segregating generation of bread wheat. Pakistan Journal of Botany 45(5), 1841-1846.

Siddique, M., Hamid, A., \& Islam, M. (2000). Drought stress effects on water relations of wheat. Botanical Bulletin of Academia Sinica 41, 35-39. CrossRef

Simova-Stoilova, L., Vassileva, V., Petrova, T., Tsenov, N., \& Demirevska, K. (2006). Proteolytic activity in wheat leaves during drought stress and recovery. General and Applied Plant Physiology, Special Issue, 2006, 91-100. CrossRef

Vicente, R., Vergara, D. O., Medina, S., Chairi, F., Kefauver, S.C., Bort, J., \& Araus, J.L. (2018). Durum wheat ears perform better than the flag leaves under water stress: Gene expression and physiological evidence. Journal of Environmental and Experimental Botany, 153, 271-285. CrossRef

Xu, X., Zhang, M., Li, J., Liu, Z., Zhao, Z., Zhang, Y., ... \& Wang, Z. (2018). Improving water use efficiency and grain yield of winter wheat by optimizing irrigations in the North China Plain. Field Crops Research, 221, 219-227. CrossRef

Zhang, D., \& Li, C. (2018). Genotypic differences and glutathione metabolism response in wheat exposed to copper. Journal of Environmental and Experimental Botany 157, 250-259. CrossRef 